\title{
The Axial Capacity of a Full Height Rectangular Opening Castellated Steel Beam with Steel Reinforcement Stiffeners
}

\author{
Muhamad Rusli A. ${ }^{*}$ and Prabowo Setiawan ${ }^{1}$ \\ ${ }^{1}$ Universitas Islam Sultan Agung, Jl. Raya Kaligawe km.4 Semarang 50112, Indonesia \\ *Corresponding author: muhamad.rusli.a@unissula.ac.id
}

(Received: 24 $4^{\text {th }}$ Mei 2021; Accepted: $31^{\text {st }}$ May 2021)

\begin{abstract}
The axial capacity of a full height rectangular opening castellated steel beam with steel reinforcement stiffeners is proven to prevent Vierendeel failure mechanism. The effect is an increase in flexural capacity of the structure. Diameter of the steel reinforcement stiffeners is revealed to have an effect on its strength in resisting axial forces occur in the structure. However, size of the diameter is limited to the strength maximum value of the steel flange section in withstanding the moment force. Using optimal design of the castellated steel structure, this research aimed to find out the increase value of the axial capacity. There were two models of steel structures employed in the study, IWF $200 \times 100 \times 5.5 \times 8$ and castellated beam $362 \times 100 \times 5.5 \times 8$, both were loaded with axial directions. Analyses were conducted using truss and pushover methods. Results of the study showed an increase in both flexural $(36.81 \%)$ and axial $(60.78 \%)$ capacities. The increase in the value of structure capacity mainly influenced by the stiffeners shortened the effective length of the structure.
\end{abstract}

Keywords: castellated; pushover; steel structure

\section{Introduction}

Castellation process on IWF section refers to a cutting, made along a web section based on a certain form, then welded to re-join. The process results in a new section with an opening on its web section. This form is called castellated steel structure. Increases in the stiffness and flexural strength of beam due to magnification on inertia of cross-section are some among advantages of this new form of castellated steel structure in construction. The height increase in the castellated steel section without having changes on its weight results in the increase in the magnitude of the inertia of the cross-section. The openings on the web section make the beam more artistic and ease the pipping installation. Despite of its strengths, the castellated beam is prone to experience vierendeel mechanism due to formation of plastic hinges on the opening ends of the web section [1] [2] [3].

The Vierendeel mechanism which occurs in the full height rectangular opening castellated steel beam decreases its capacity, thus it becomes smaller than the earlier section. This happens due to the plastic hinges at the opening ends of the web section [1] [3] [8]. The use of a cross-reinforcing steel stiffener in the full height rectangular opening castellated steel beam prevents the Vierendeel failure, thus, increases the flexural capacity of the castellated steel beam [1]. See Fig. 1 for the position and form of reinforcement steel stiffeners. 


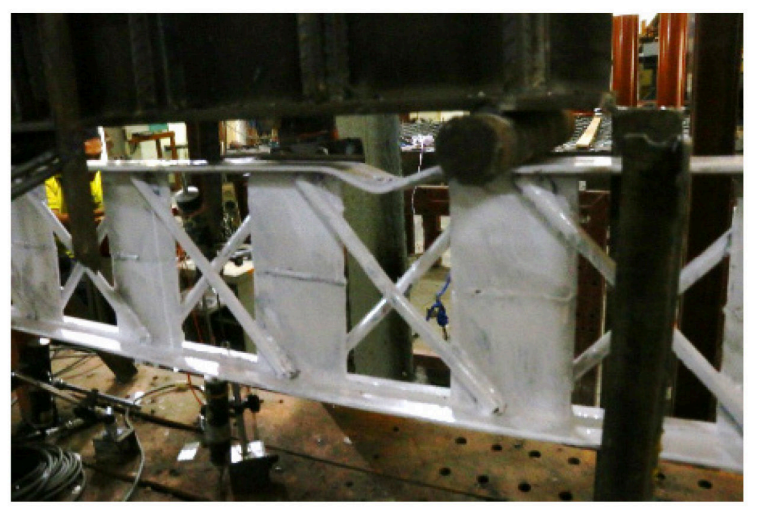

Fig. 1. The diagonal stiffener on the full height rectangular opening castellated beams

In addition to improving the flexural capacity, the steel reinforcement stiffeners in the castellated structures can also be used to increase the value of axial capacity. The smaller the value of an effective span of a structure, the less likely the local buckling failure to occur [4]. This research aimed to obtain the increase in the axial capacity influenced by the castellation process and the addition of steel reinforcement stiffeners on IWF section $200 \times 100 \times 5.5 \times 8$.

\section{Research Method}

Test object of the study was IWF section $200 \times 100 \times 5.5 \times 8$ modified into the castellated model with a dimension of $362 \times 100 \times 5.5 \times 8$. This castellated section had a cross-sectional height of $\mathrm{h}=$ $362 \mathrm{~mm}$, cross-sectional width of $\mathrm{b}=100 \mathrm{~mm}$, flange thickness of $\mathrm{t}_{\mathrm{f}}=8 \mathrm{~mm}$, and web thickness of $t_{w}=5.5 \mathrm{~mm}$. Grade of steel used in the study belonged to BJ37. This material was selected as it had a yield stress of $f_{y}=240 \mathrm{Mpa}$. The span of structure, $\mathrm{L}=3 \mathrm{~m}$, was determined in accordance with its limit to avoid lateral torsional buckling [3]. The castellated structure had a hole width of $130 \mathrm{~mm}$. A steel reinforcement with a diameter of $16 \mathrm{~mm}$, an optimization from the castellated structure with the width of $130 \mathrm{~mm}$ [5] [9], was used as a stiffener in the structure. The plastic moment capacity of IWF beam (Mp) were calculated using following equation (1) [6].

$$
M_{p}=f_{y} \times Z_{x}
$$

See Table 1. for the specifications of the castellated steel structure model and Fig. 2 for the sketch of longitudinal cross-section .

Table 1. The dimension of the castellated steel structure

\begin{tabular}{lc}
\hline Elements of castellated section & Dimension $(\mathrm{mm})$ \\
\hline Height of cross-section & 362 \\
Width of cross-section & 100 \\
Web thickness & 5.5 \\
Flange thickness & 8 \\
Opening/hole width & 130 \\
Non-offset length of stiffener & 239 \\
\hline
\end{tabular}




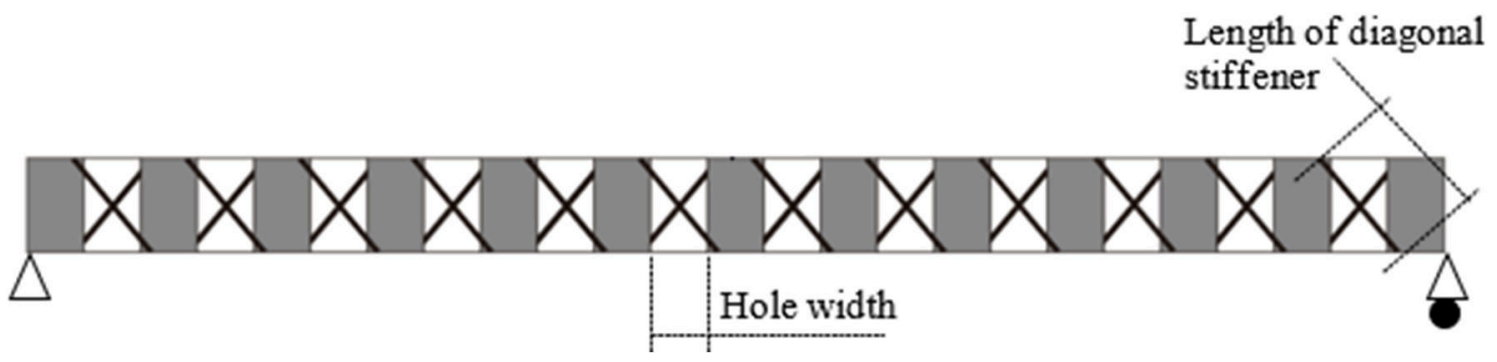

Fig. 2. The longitudinal cross section of the castellated structure

\subsection{Truss Analysis}

Diagonally positioned stiffener formation made the load transfer in the castellated structure similar to the one of the formation in the truss structure system [1]. The truss system analysis eased a planning for castellated structure. In the truss analysis, only compression and tension element were taken into account to determine the load capacity value. Below is the equation used to calculate the tensile capacity according to SNI-1729-2015 [6]:

$$
P_{n}=f_{y} \times A_{g}
$$

$\mathrm{P}_{\mathrm{n}}=$ tension axial capacity $(\mathrm{N})$

$\mathrm{f}_{\mathrm{y}}=$ yield stress of steel $(\mathrm{MPa})$

$\mathrm{A}_{\mathrm{g}}=$ Cross-section area $\left(\mathrm{mm}^{2}\right)$

Calculation of compression elements based on SNI-1729-2015 was determined in accordance with the type of geometric shape of the cross section [7]. In the castellated structures, compressive elements had solid rectangular and circle shapes. Therefore, capacity of the compression members was only determined based on flexural buckling calculated by the following equation:

$$
P_{n}=f_{c r} \times A_{g}
$$

$\mathrm{A}_{\mathrm{g}}$ was the cross-section area and $\mathrm{f}_{\mathrm{cr}}$ was the critical stress (MPa) determined based on the effective slenderness ratio value of the cross-section calculated using the following equation:

$$
\lambda=\frac{K L}{r}
$$

$\lambda=$ Effective slenderness ratio

$\mathrm{K}=$ Effective length factor

$\mathrm{L}=$ Length of the span

$\mathrm{r}=$ Gyration radius

From calculating the slenderness ratio, the value of critical stress was enumerated using the following formula:

$$
\begin{gathered}
\text { If } \lambda \leq 4.71 \sqrt{\frac{E}{f_{y}}} \text { or } \frac{f_{y}}{f_{e}} \leq 2.25, \\
f_{c r}=\left[0.658^{\frac{f_{y}}{f_{e}}}\right] f_{y}
\end{gathered}
$$




$$
\begin{gathered}
\text { If } \lambda>4.71 \sqrt{\frac{E}{f_{y}}} \text { or } \frac{f_{y}}{f_{e}}>2.25, \\
\text { Then } f_{c r}=0.877 f_{y}
\end{gathered}
$$

$\mathrm{E}=$ modulus of elasticity $(\mathrm{MPa})$

$\mathrm{f}_{\mathrm{e}}=$ elastic bending stress $(\mathrm{MPa})$

The elastic bending stress $\left(f_{e}\right)$ was calculated using the following equation:

$$
f_{e}=\frac{\pi^{2} E}{\lambda^{2}}
$$

\subsection{Pushover Analysis}

In general, the pushover analysis stage was carried out with a two dimensional frame model on SAP2000. The loading pattern, steel hinge properties and load case pushover should be defined in the model [4]. After an analysis process was carried out, the output result could be found in the pushover analysis curve. The castellated structure model on SAP2000 is shown in Fig. 3.
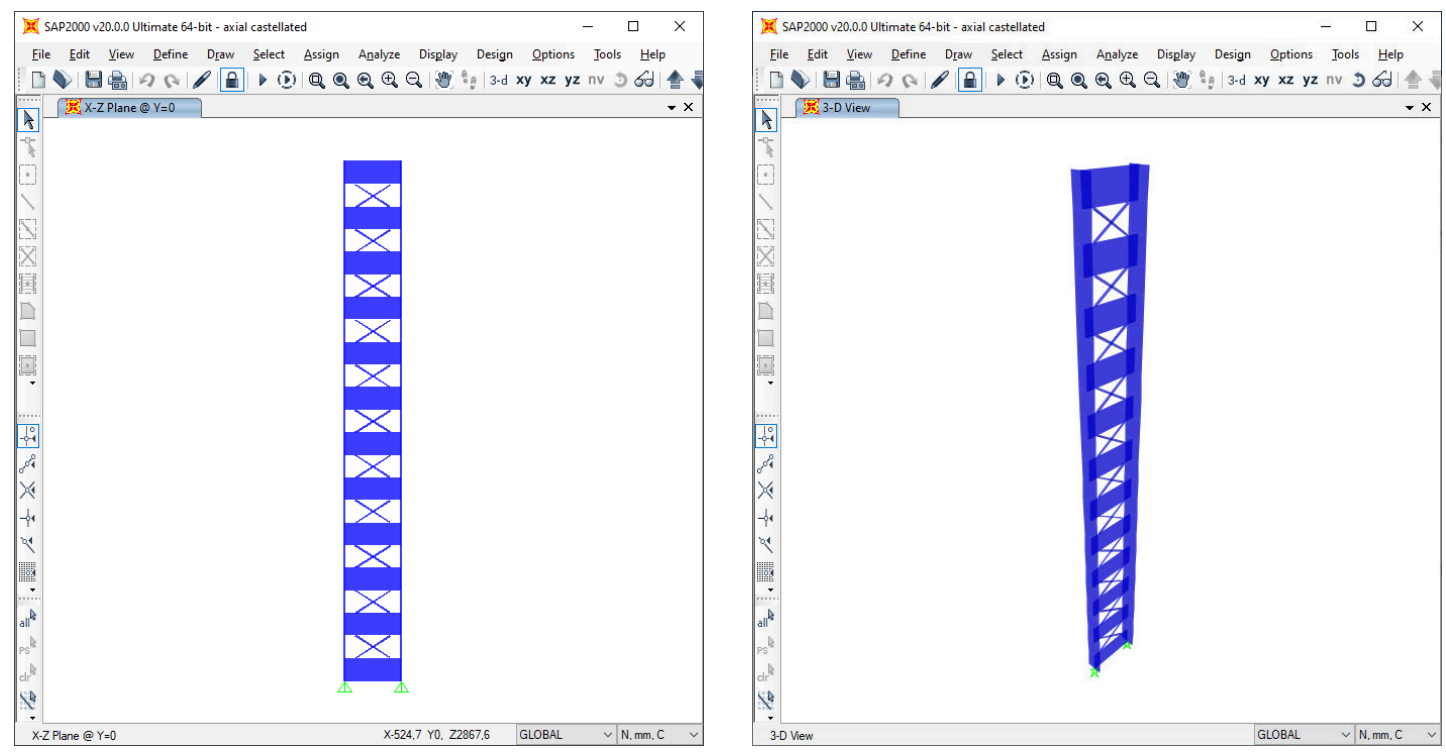

Fig. 3. The modelling of the castellated steel column structure on SAP2000

Steel hinge properties were determined based on the material stress and deformation which occurred in the castellated beam elements. Compressive structural elements would experience a critical stress, while tensile structural elements would experience yield stress. The deformation value of the elements was calculated using the following equation:

$$
\delta=L \times \varepsilon
$$

$\delta$ was the axial displacement $(\mathrm{mm}), \mathrm{L}$ was the length of the calculated element span $(\mathrm{mm})$, and $\varepsilon$ was strain value of material $(\mathrm{mm} / \mathrm{mm})$.

\section{Results and Discussion}

3.1 The moment strength of the strong axis direction 
Analysis results in nominal moment strength of the strong axis direction showed that the strength review was seen from the flange strengh and steel reinforcement elements in resisting the compressive forces [6]. The nominal compressive forces which occured in the flange and stiffener can be seen in Table 2 below:

Table 2. The compressive strength of the elements in castellated structure

\begin{tabular}{lcc}
\hline Element(s) & \multicolumn{2}{c}{ Compressive strength } \\
\cline { 2 - 3 } & $\begin{array}{l}\text { Condition of fixed } \\
\text { supported system }\end{array}$ & $\begin{array}{c}\text { Condition of pinned } \\
\text { supported system }\end{array}$ \\
\hline Flange & $186.13 \mathrm{kN}$ & $169.6 \mathrm{kN}$ \\
Stiffener & $46.11 \mathrm{kN}$ & $40.23 \mathrm{kN}$ \\
\hline
\end{tabular}

Using data in Table 2, an iteration analysis was carried out to obtain maximum centered load value which the castellated structure could withstand. From the iteration process, the maximum load value of $89.84 \mathrm{kN}$ was obtained. With the load, the axial force occured on the flange element was $186.13 \mathrm{kN}$ while the axial force on the reinforcing steel was $26.77 \mathrm{kN}$. Since the value of the axial force was equal to the compressive strength on the flange element, failure was indicated to occur in the element (flange element). However, the maximum load of $89.84 \mathrm{kN}$ could be converted to the nominal moment strength of $67.38 \mathrm{kNm}$.

Results of the pushover analysis using SAP 2000 program showed that the castellated structure was able to withstand a maximum load of $88.74 \mathrm{kN}$. This maximum load was converted into a nominal moment strength of $66.56 \mathrm{kNm}$. See Fig. 4. and Fig. 5. below to find out the outputs of the pushover SAP 2000 analysis.

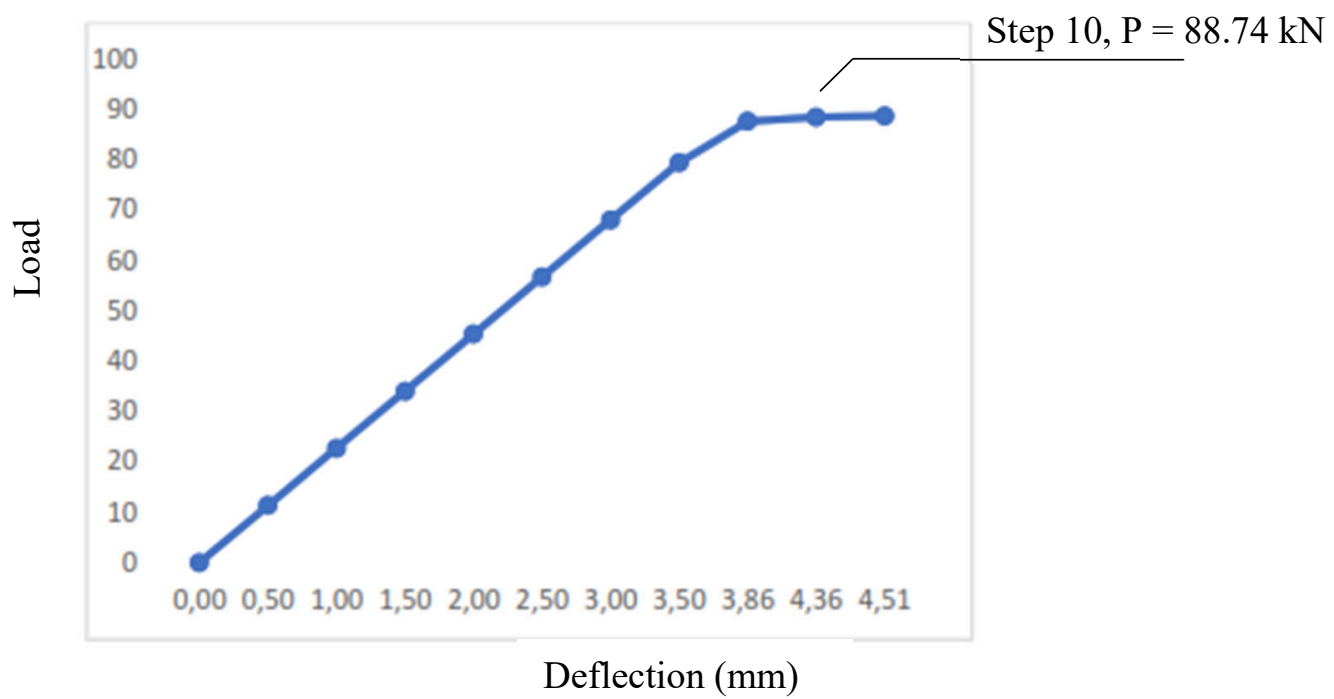

Fig. 4. The load-deflection curve of the pushover SAP 2000 analysis

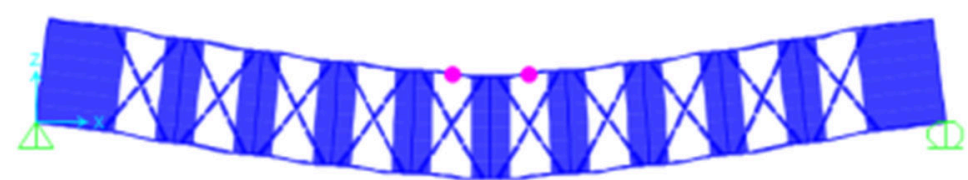

Fig. 5. The conditions of the deflection and failure mechanism in the castellated structure 
As a comparison, the flexural strength of IWF section $200 \times 100 \times 5.5 \times 8$ was calculated based on SNI-1729-2015 and resulted in a value of $48.65 \mathrm{kNm}$. This means manufacturing process of the castellated structure could increase the value of flexural strength from $48.65 \mathrm{kNm}$ to $66.56 \mathrm{kNm}$ (increase 36.81\%).

\subsection{Moment Capacity in Weak Axis Direction}

In compact section classification, the weak axis direction nominal moment value of IWF section was calculated based on the plastic section modulus strength of the flange element [6]. The castellated steel structure $362 \times 100 \times 5.5 \times 8$ had a yield section modulus value of $40000 \mathrm{~mm}^{3}$. Nominal moment of the weak axis direction was obtained by multiplying the plastic section modulus with the stress value of the steel material. The result was a nominal moment in the weak axis direction of $9.6 \mathrm{kNm}$. The nominal moment of the weak axis direction of IWF section 200x100x5.5x8 was calculated using the same method and resulted in the value of $9.93 \mathrm{kNm}$. From this analysis, the castellated system did not have a significant effect in increasing the nominal moment of the weak axis direction. See Fig. 6. below for more detail.

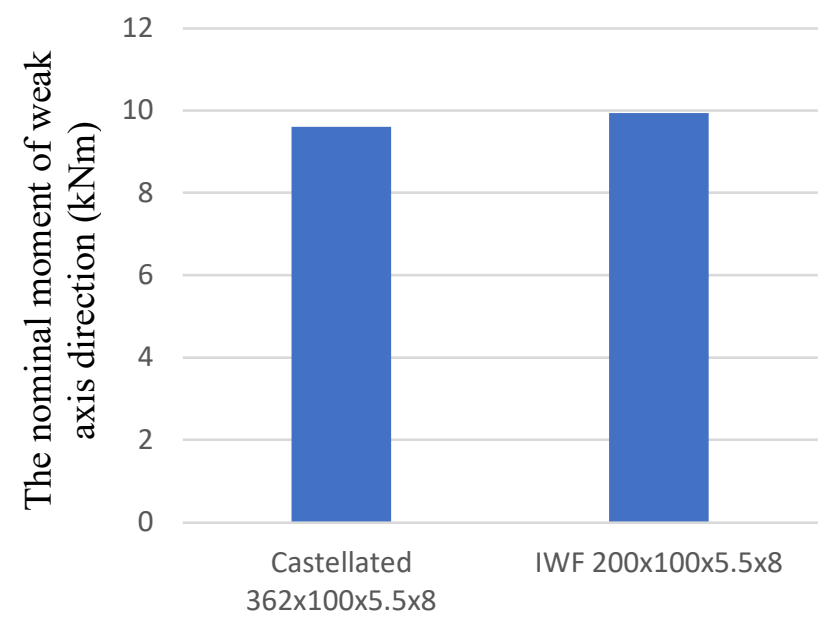

Fig. 6. The nominal moment of the weak axis direction

\subsection{The axial strength analysis}

The critical stress was calculated using equations (4), (5), (6), (7), (8), and (9). From these calculations a critical stress value of $97.89 \mathrm{Mpa}$ was obtained. The critical stress affected the axial strength value of IWF section. Using the equation (3), the axial strength value of IWF section of $255 \mathrm{kN}$ was obtained.

See Table 3 and Fig. 7 below for the pushover analysis output of the axial compressive strength of the castellated steel structure. The strength value of the structure is $409.89 \mathrm{kN}$. It means there happened a significant increase $(60.78 \%)$ from the original strength of the previous IWF section. The cross reinforcement on the structure acted as a stiffener, as a result, the effective length value, $\mathrm{Lb}$, was shorter. The smaller the value of the effective length of the structure, the greater the compressive strength.

Table 3. The axial strength of the castellated steel structure from the pushover analysis

\begin{tabular}{ccc}
\hline Step & $\begin{array}{c}\text { Deformation } \\
(\mathrm{mm})\end{array}$ & $\begin{array}{c}\text { Axial Capacity } \\
(\mathrm{kN})\end{array}$ \\
\hline 0 & 0.00 & 0.00 \\
\hline 1 & 0.60 & 104.13 \\
\hline 2 & 1.20 & 208.23 \\
\hline
\end{tabular}




\begin{tabular}{ccc}
\hline Step & $\begin{array}{c}\text { Deformation } \\
(\mathrm{mm})\end{array}$ & $\begin{array}{c}\text { Axial Capacity } \\
(\mathrm{kN})\end{array}$ \\
\hline 3 & 1.80 & 312.29 \\
\hline 4 & 2.29 & 397.59 \\
\hline 5 & 3.15 & 409.89 \\
\hline 6 & 3.15 & 119.28 \\
\hline 7 & 3.95 & 129.84 \\
\hline 8 & 4.55 & 129.65 \\
\hline 9 & 5.15 & 129.47 \\
\hline 10 & 5.54 & 129.34 \\
\hline
\end{tabular}

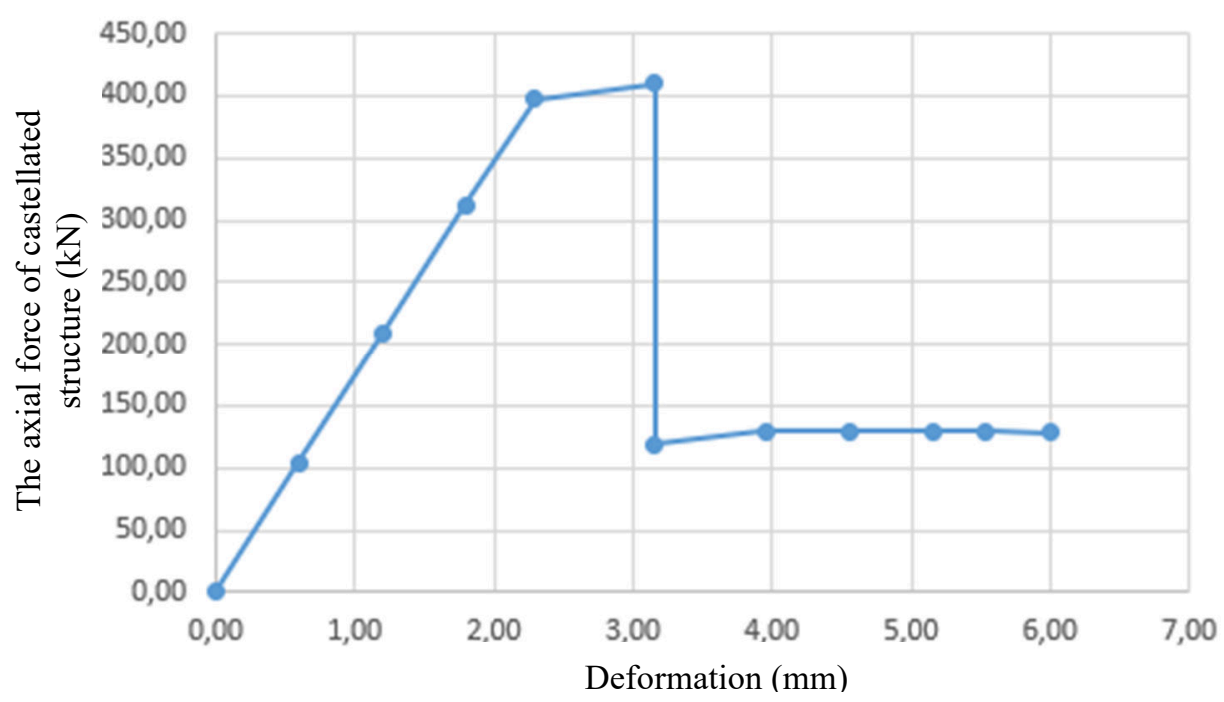

Fig. 7. The curve of the axial force-deformation from the pushover analysis.

\subsection{The curve of moment-axial interaction}

Curve of moment-axial interaction was used to determine the safety of the column structure in resisting the combination of axial and moment forces. For steel structures, a moment-axial interaction was calculated by the following equations, (11) and (12):

$$
\begin{aligned}
& \text { If } \frac{P_{r}}{P_{c}} \geq 0.2 \text { then } \frac{P_{r}}{P_{c}}+\frac{8}{9}\left(\frac{M_{r x}}{M_{c x}}+\frac{M_{r y}}{M_{c y}}\right) \leq 1.0 \\
& \text { If } \frac{P_{r}}{P_{c}}<0.2 \text { then } \frac{P_{r}}{2 P_{c}}+\left(\frac{M_{r x}}{M_{c x}}+\frac{M_{r y}}{M_{c y}}\right) \leq 1.0
\end{aligned}
$$

$\mathrm{P}_{\mathrm{r}}=$ axial force $(\mathrm{N}), \mathrm{P}_{\mathrm{c}}=$ compressive strength $(\mathrm{N}), \mathrm{M}_{\mathrm{rx}}=$ moment force of a strong axis direction $(\mathrm{Nmm}), \mathrm{M}_{\mathrm{ry}}=$ moment force of a weak axis direction $(\mathrm{Nmm}), \mathrm{M}_{\mathrm{cx}}=$ nominal moment capacity of a strong axis direction (Nmm), $\mathrm{M}_{\mathrm{cy}}=$ nominal moment capacity of a weak axis direction $(\mathrm{Nmm})$.

The moment-axial interaction curves were obtained for both strong and weak axes as shown in Fig. 8. and Fig. 9. below. 


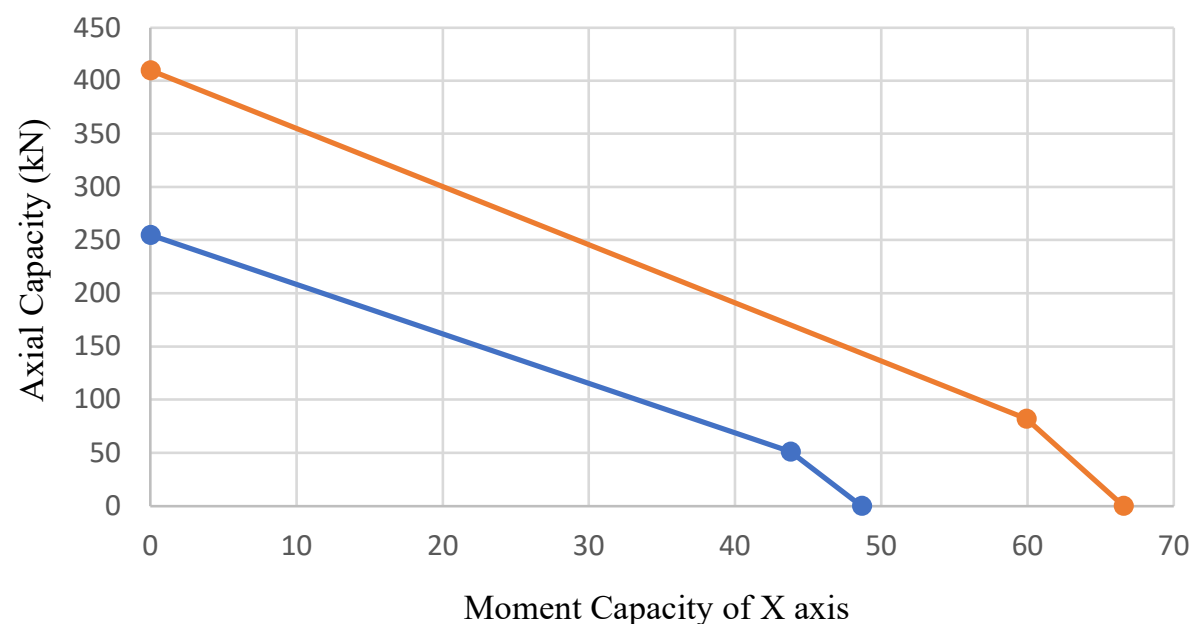

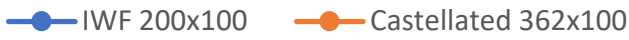

Fig. 8. The moment-axial Interaction curve from the strong axis direction

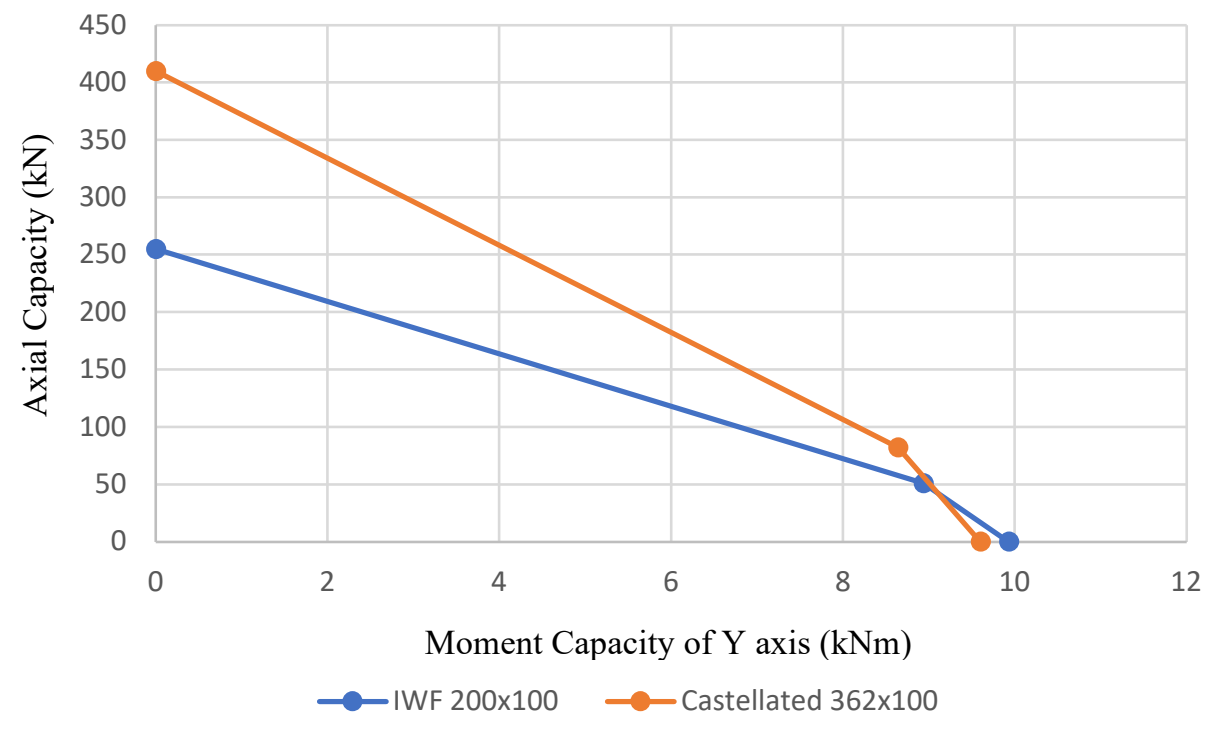

Fig. 9. The moment-axial interaction curve from the weak axis direction

Fig. 9. and Fig. 10. show the combination of nominal axial and nominal moment capacities. Highest increase occurred only in the strong axis direction, but not in the weak axis direction. Rather increasing the nominal moment for the weak axis, the castellated process only effectively increased the nominal moment value for the strong axis direction.

\section{Conclusion}

The local conclusions to be drawn based on the study are :

1. There happened the increase of $36.81 \%$ in the nominal moment of the strong axis direction due to the castellation process. Steel reinforcement as a stiffeners in the study was reported to be capable of negating the effect of Vierendeel.

2. The castellation process did not affect the nominal moment value of the weak axis direction. 
3. The compressive axial strength in the castellated steel structure increased by $60.78 \%$. Fairly tight installation on the reinforcement stiffeners caused this significant raise, as the result, the value of effective width became smaller and reduced the effect of the local buckling on the structure.

\section{Acknowledgements}

We would like to acknowledge and thank Universitas Islam Sultan Agung Semarang Indonesia. This University provided a full funding support to complete this project. Our sincere gratitude is further extended to LPPM UNISSULA without their supportive guidance and supervision, this project would not be duly completed.

\section{References}

[1] Muhamad Rusli A, Ali Murtopo, Iman Satyarno, M. Fauzie Siswanto (2018), Full height rectangular opening castellated steel beam with diagonal stiffener, Applied Mechanics and Material, Trans Tech Publications, Switzerland

[2] Muhamad Rusli A., Prabowo Setiawan, Dessy Maimunah, and Destia Wulandari (2019), The Effect of Hole Width on Full Height Rectangular Opening Castellated Steel Beam with Diagonal Stiffener Concerning Its Flexural Capacity, Journal of Advanced Civil and Environmental Engineering, Vol.2 No.2 pp 76-84

[3] A.T.C.R.D. Oliveira (2012), Flexural Behaviour of rectangular hole pattern castellated beam with reinforcement mortar composite (in Indonesia) Master Thesis (Universitas Gadjah Mada, Yogyakarta)

[4] Dewobroto, Wiryanto (2016), Steel Structure - behavior, analysis \& design - AISC 2010 $2^{\text {nd }}$ Edition (in Indonesia), Penerbit Jurusan Teknik Sipil Universitas Pelita Harapan Jakarta

[5] Chahyo Tri Adinata dan Enggal Sukadana (2019), Influence of different diameter size of steel bar reinforcement on rectangular opening castellated steel beam, undergraduate Thesis (Universitas Islam Sultan Agung, Semarang), (in Indonesian)

[6] Badan Standarisasi Nasional (2015), SNI 1729 2015: Specification for steel structure building (in Indonesia), (Jakarta: Badan Standarisasi Nasional), in Indonesian.

[7] Computer \& Structures Inc. (2011), CSI Analysis reference manual for SAP2000 ${ }^{\circledR}$, $E_{T A B S}{ }^{\circledR}, S A F E^{\circledR}$ and CSiBridge ${ }^{T M}$, (Berkeley, California: University Avenue)

[8] I. Satyarno, D. Sulistyo, D. Heldita, A.T.C.R.D. Oliveira (2017), Full height rectangular opening castellated steel beam partially encased in reinforced mortar, Procedia Engineering pp 176-184

[9] Dessy Maimunah and Destia Wulandari (2019), Influence of different hole width on rectangular opening castellated steel beam with steel bar reinforcement (in Indonesia) undergraduate Thesis (Universitas Islam Sultan Agung), in Indonesian. 